\title{
Correction to: The contribution of iron deficiency to the risk of peripartum transfusion: a retrospective case control study
}

\author{
H. VanderMeulen ${ }^{1 *}$, R. Strauss ${ }^{2}$, Y. Lin ${ }^{2,3}$, A. McLeod ${ }^{4}$, J. Barrett ${ }^{5}$, M. Sholzberg ${ }^{3,6,7}$ and J. Callum ${ }^{2,3^{*}}$
}

\section{Correction to: BMC Pregnancy Childbirth (2020) 20:196 https://doi.org/10.1186/s12884-020-02886-z}

Following publication of the original article [1], we have been notified that there is a missing conflict of interest. The Competing interests section is updated as follow:

Dr. Michelle Sholzberg has received honoraria for advisory boards from Pfizer. Dr. Yulia Lin has received research grants from Novartis and consulting fees from Pfizer. The remaining authors declare that they have no competing interests.

\section{Author details}

'Department of Medicine, Division of Hematology, University of Toronto,

Toronto, Canada. ${ }^{2}$ Department of Laboratory Medicine and Molecular Diagnostics, Sunnybrook Health Sciences Centre, Toronto, Canada.

${ }^{3}$ Department of Laboratory Medicine and Pathobiology, University of Toronto, Toronto, Canada. ${ }^{4}$ Department of Medicine, Sunnybrook Health Sciences Centre, Toronto, Canada. ${ }^{5}$ Department of Obstetrics and Gynecology, Sunnybrook Health Sciences Centre, Toronto, Canada. ${ }^{6} \mathrm{Li}$ Ka Shing Knowledge Institute, Toronto, Canada. ${ }^{7}$ Department of Medicine, St. Michael's Hospital, Toronto, Canada.
Published online: 17 April 2020

\section{Reference}

1. VanderMeulen $\mathrm{H}$, et al. The contribution of iron deficiency to the risk of peripartum transfusion: a retrospective case control study. BMC Pregnancy Childbirth. 2020;20:196. https://doi.org/10.1186/s12884-020-02886-z.

The original article can be found online at https://doi.org/10.1186/s12884020-02886-Z

* Correspondence: heather.vandermeulen@medportal.ca;

jeannie.callum@sunnybrook.ca

'Department of Medicine, Division of Hematology, University of Toronto, Toronto, Canada

${ }^{2}$ Department of Laboratory Medicine and Molecular Diagnostics, Sunnybrook Health Sciences Centre, Toronto, Canada

Full list of author information is available at the end of the article

(c) The Author(s). 2020 Open Access This article is licensed under a Creative Commons Attribution 4.0 International License, which permits use, sharing, adaptation, distribution and reproduction in any medium or format, as long as you give appropriate credit to the original author(s) and the source, provide a link to the Creative Commons licence, and indicate if changes were made. The images or other third party material in this article are included in the article's Creative Commons licence, unless indicated otherwise in a credit line to the material. If material is not included in the article's Creative Commons licence and your intended use is not permitted by statutory regulation or exceeds the permitted use, you will need to obtain permission directly from the copyright holder. To view a copy of this licence, visit http://creativecommons.org/licenses/by/4.0/. The Creative Commons Public Domain Dedication waiver (http://creativecommons.org/publicdomain/zero/1.0/) applies to the data made available in this article, unless otherwise stated in a credit line to the data. 